Canadian Journal of Family and Youth, 8(1), 2016, pp 153-172

ISSN 1718-9748 @ University of Alberta

http://ejournals.library.ualberta.ca/index/php/cjfy

\title{
Can Canadian Women Have it All? How Limited Access to Affordable Child Care Restricts Freedom and Choice
}

\author{
Nicole Telford
}

\begin{abstract}
The objective of this essay is to provide an historical account of the attempts made to implement a universal child care policy in Canada. Since World War II, we have been seeing large numbers of women entering the workforce and have had no centralized child care policy in place. This contributes to role strain on women as there appears to be little choice in work and family life. This paper explores the effort made by the feminist movement and women's advocates to establish a universal child care system. I hope to achieve a clear understanding that the need for child care remains an equality issue. Throughout this paper, I will shed light on the effects child care has on women, their families, and society. I will also address the current policies in place and what is to come under the new Liberal government.
\end{abstract}

Nicole Telford is an undergraduate student in Sociology at MacEwan University. While maintaining her studies, Nicole also works for the Government of Alberta as a Services Coordinator with Alberta Supports. She aspires to complete her Bachelor of Social Work and maintain focus on supporting Canada's vulnerable population through research and frontline service. 
Telford

\section{Introduction}

Women today are faced with insurmountable pressure to achieve professional and family success though many have limited support in doing so. The women's rights movement encouraged messages of freedom and choice (Mckenna, 2015, p. 41), however, government policies have changed little to support working mothers and child care. The notion of choice for women and families is often prohibited by the exorbitant costs of placing children in nonparental care. The median monthly cost of child care in Canada is $\$ 761$, making it one of the largest expenses to consider when raising a child (Albanese \& Rauhala, 2015, p. 256). As Erin McKenna (2015) postulates, "what does it mean to live in a culture where to parent, to form a family, and to value an ethic of mutual care and responsibility is the 'right' of only the wealthy (p. 42)?" An additional non-monetary price tag that comes with placing children in child care is stress on women having to balance both a professional career and child-rearing, thus leading to role strain (Falkenberg \& Monachello, 1990, p. 341).

The goal of this paper is to provide a qualitative analysis of the efforts made to support women in the labour force balancing child care in post-war Canada. World War II marked the beginning of women entering the work force in large waves and nearly 75 years later Canada is still without universal child care. Women in the workforce have transformed the traditional family dynamic (Herring \& Wilson-Sadberry, 1993, p. 314), however, government policies have not changed nearly enough to support this. Canada has shifted from the welfare state once known to a decentralized, neoliberal government that has a "weakened" influence on social program funding (Mckenna, 2015, p. 43). I hypothesize that women's inequality is perpetuated by the limited access to affordable, universal child care. The freedom to be educated, pursue a career, 
Can Canadian Women Have it All?

and maintain a household should be a matter of choice available to all women and supported by our federal and provincial governments.

\section{Literature Review}

The fight for a universal child care policy in Canada has been an ongoing debate since the close of WWII. Women, advocacy groups, and government bodies alike have all acknowledged and fought for a woman's right to child care and, ultimately, equality. Research has overwhelmingly shown that the lack of a centralized approach to child care has been burdensome to women and families for decades. The issue at large is women's equality, however, other areas of family are also impacted by this including: economic hardship, role strain, and early childhood development.

Statistics have shown that the vast majority of Canadian families require a dual-income household to be financially stable. Though it should be a matter of choice for women to enter the workforce and/or raise a family, current economic conditions do not allow this freedom. Census data has indicated that there has been a large increase in the amount of dual-earning households (Falkenberg \& Monachello, 1990, p. 339) since the 1970s. The cost of living is perpetually escalating; the cost of child care is not excluded from this. Families, women in particular, are often forced to leave paid employment as the cost of childcare consumes their monthly wage. Those women who are left balancing between the two experience a role strain, with little to no support from the government or their spouse. As Falkenberg and Monachello (2014) have found, mothers were working more outside the home while fathers had not increased their responsibilities within the home (p. 341). 
Telford

One province in particular has stood out amongst the rest in its achievement of a universal child care program. Quebec has been a leader in the country, offering a low-cost formal child care without limitations to employment or income. The province assumed jurisdictional responsibility for child care, bypassing the federal government which has yet to implement a universal program (Cleveland \& Krashinsky, 2001 p. 92). This approach is unique to Quebec as other provinces maintain the federal government plays a "leadership" role in child care (p. 93). The commonality in my research has shown that there needs to be a complete dismantling of the current child care policies at all levels of government in order to achieve a centralized set of principles under which each provincial and territorial jurisdiction can act (Friendly, 2000 \& Mckenna, 2005 \& Cleveland, 2013).

\section{Women's Entry into the Workforce}

World War II saw women enter paid labour in Canada out of necessity to support their families and also to support war efforts (Pasolli, 2015, p. 2). To assist with this transition, officials in Ottawa produced a variety of photographs depicting fictional women maintaining an active social and family life while also going to work in the factories. A particularly important woman was Mrs. Jack Wright, who was frequently shown "maintaining a happy family life, eating breakfast with her sons every morning, tucking them into bed at night, and spending leisure time with them on weekends" (p. 2). Pasolli (2015) attributes this perception of a seamless schedule to the Provincial-Dominion Wartime Daycare Nursery Agreement (WDNA) (p. 2). In 1942 the federal government developed a fifty-fifty cost sharing agreement with provincial governments for mothers assisting in the war effort (p. 2). From the enactment of the WDNA through to 1946 a total of 34 day-care nurseries were established in Ontario and Quebec, 
providing relief for some working mothers (p. 2). This agreement, however, did not universally capture all working mothers in Canada. Few provinces participated in the program resulting in limited nursery availability and within them lengthy waitlists and inaccessible hours of operation. (p. 3). Gunda Lambton, a British immigrant described her own frustration with the system:

I have no relations. I couldn't possibly impose on friends...I can see that those who'll profit from government nursery schools will be middle-class women who live in their own homes, can take time to find a job, have a mother - or other close relation - living nearby. Those who have husbands in the army get an allowance, a 'mother's allowance' if they're Canadian citizens. All that is out of my reach.'

The WDNA ended with the war in 1946 with the myopic view that women would return back to their domestic engineering positions. Unfortunately this wasn't the case, the social and economic effects of war were felt throughout the country and many women continued to participate in the labour force out of necessity (as cited in Veterans Affairs Canada). Demand for daycare services was assumed to be for the poor or working-class women, while society at large still held mixed feelings on how these services would impact their families (p. 7).

The issue of child care for working mothers laid relatively dormant post-war (Dobrowolsky \& Jenson, 2004, p. 159). Child care was not acknowledged as a citizen right (p.159), and ambivalence about working motherhood still lingered (Pasolli, 2015, p. 7).

Feminists and society alike were uncertain of what women in paid labour meant for children and families. In 1965, prior to the second wave of feminism, federal and provincial governments banded together to fund subsidized child care, with limitations, meant for those "in need or in danger of becoming in need". At this point, it seemed the government had begun to assume responsibility for child care and attempted to act as a safety net for Canadians (Dobrowolsky \&

\footnotetext{
${ }^{1}$ As referenced in Pasolli, L. (2015). "I ask you, Mr. Mitchell, is the emergency over?": Debating Day Nurseries in the Second World War. Canadian Historical Review, 96(1), 1-31. doi:0.3138 (p.4)
} 
Telford

Jenson, 2004, p. 159). Mahon and Philips described the government's primary goal as '[enabling] the individual to attain or regain the fullest measure of self-support of which he is capable' (p. 159). The concern surrounding this was that women were largely absent in the intention, support was aimed at the male breadwinner, portrayed as the "dominant family form" (p. 159). By the late 1960s, the second wave of feminism was gaining ground by individuals, advocacy groups, communities, social movement organizations, and the federal government itself to further fight for gender equality (p. 159).

\section{Second Wave Feminism and Child Care}

In 1968 the Royal Commission on the Status of Women (RCSW), led by Florence Bird, began a six-month public investigation on the problems experienced by women (Lipkin, 2006). During this period, 378 written briefs were submitted, closer examination of 273 showed that 74 percent of women raised concern about women's employment and child care (Dobrowolsky \& Jenson, 2004, p. 160). The results published in 1970 called on the federal government to implement a national child care plan that would support women entering the workforce (Cleveland \& Colley, 2013 p. 173). Bird and her colleagues argued that women should have the freedom to choose to enter the workforce or stay home with their children and that this gap hindered their opportunity to do so (Bird, 1970, p. 201). The panel recommended a multi-level government approach with day-care fees placed on a sliding scale according to family income (p. 201).

The RCSW findings led to the formation of the Canadian Advisory Council on the Status of Women (CACSW) and also inspired more women's rights groups to focus on child care as a right, including the National Action Committee on the Status of Women (NAC) (Dobrowolsky \& 
Jenson, 2004, p. 160). Two months after forming, the CACSW encouraged all levels of government to "come to grips with the problem of child care in Canada" (p. 161) and firmly stated its belief of "a good-quality, non-profit, affordable system of child care available to anyone across Canada" with an emphasis on child care being an "economic necessity for women" (p. 161).

\section{Shift from the Welfare State to Neoliberalism}

The rising empire of neoliberalism began as early as the 1970s but did not truly make its presence known until the late 1980s. Liberal governments across the world began abandoning the Keynesian economics favoring instead "deregulation, privatization, regressive tax reforms, erosion and dismantling of social services, campaigns of state deficit- and debt-reduction, the opening of doors to foreign investment, and attacks on trade-union rights" (Carroll \& Shaw, 2001, p. 196). McKenna (2015) argues that using this "individual solution to [solve] socially generated problems" leaves "the individual held responsible for their decisions; choice becomes the logic against which capitalism covers its tracks" (p. 44). Ultimately, the introduction of neoliberalism shifted the "blame" from the government back onto the individual, rather, the woman who was responsible for the "choice" she made.

\section{Women Left Behind}

Between the late 1980’s and early 1990’s a “shift [in] patterns of representation” took place in Canada. As mentioned earlier, Canada was leaving the notion of a welfare state behind and adopting a more neoliberal ideal. To align with this, government agencies and advocacy groups exchanged the word "women" for “child”. Women's rights were set aside while child

care advocates sought to solve the issue of children and poverty (Dobrowolsky \& Jenson, 2004, 
Telford

p. 161). Women were not only left behind by the agencies, feminists also began to abandon their fellow woman. Shortly after the CACSW was created, a "false sense of universality" towards women's rights was evident. The idea that "'all mothers' needed, wanted, or preferred the same child care services" became a point of contention (p. 161). The other issue was that not all feminists wanted to exchange the name "woman" for "mother". While support waned, throughout the 1980s efforts were made by the Canadian Day Care Advocacy Association (CDCAA) and the federal government's Task Force on Child Care, though once again little was achieved to create a child care umbrella over the country.

Aligning with a decentralized, market-based approach the Conservative government answered the decades-long pleas for a universal child care system with the introduction of Bill C-144; the Canada Child Care Act in 1987. This submission marked the first formal child care legislation from the federal government. Unfortunately, child care advocates criticized the bill arguing that it would "[reduce] federal leadership" (Cleveland \& Krashinsky, 2004, p. 33) and gave more responsibility to the commercial sector and would not be the "publicly funded, universally accessible child care" that advocates had long been fighting for (Dobrowolsky \& Jenson, 2004, p. 163). Fortunately for women and children, this proposal did not make it past the Senate (Friendly, 1991, p. 32). According to Dobrowolsky and Jenson (2004), this marked the "high[est] point of feminist organizing for child care as a right of women citizens" (p. 167) At this point in time, the Conservative government focused its attention on "low income and disadvantaged children" abandoning child care once again (p. 167). 


\section{A Balancing Act - Career and Family}

Falkenberg and Monachello (1990) postulate that women experience conflict between self-concept and their behaviours, largely due to the expectations society has of them. Women are socialized from birth to become domestic engineers, however, their own "self-concept and needs relate to the development of a career outside the home" (p. 343). Furthermore if a woman is career-oriented, this trait is often associated with males, rendering her subject to scrutiny from society at large (p. 341). Role strain occurs, inevitably, when women are trying to balance their career while also maintaining a functional household; thus achieving the societal expectation of housemaker. These researchers have found that in dual-income families women experience a greater "role overload" than men, as it is expected that the woman's family role will exceed that of her husband (p. 341).

Falkenberg and Monachello (2014) also found that while mothers were working more outside the home, fathers had not increased their responsibilities within the home (p. 341). In a study conducted on balancing dual-income households, Wada and colleagues interviewed families in attempt to understand how parents feel their time is distributed, below is one working woman's account (p. 268):

I'm a to-do list person, and a to-do list sometimes seems endless and overwhelming....Y You don't have time to rest, you don't have time to relax. Just makes you out of balance because there are so many things to do to do to do to do.

Research exploring coping mechanisms for working women emphasized merely one consistently used method, the importance of a support system, both emotional and physical (Falkenberg and Monachello, 1990, p. 345). While one may argue that males could alleviate a woman's role strain, by taking on additional responsibilities at home, accessibility to child care services could act as a greater support. The sole fact that women are expected to manage two full-time jobs, 
Telford

both in paid and household labour, is deplorable and does not exercise the notion of "freedom" nor "choice."

\section{Dual Income as a Necessity}

As the phrase often goes, "the proof is in the pudding". The newly elected Liberal government states that 7 out of 10 two-parent families are working, a number that has doubled over the past 40 years (as cited in Liberal Platform). Additionally, according to Falkenberg and Monachello (1990) "census data indicates that in 1986 both husband and wife were employed in over 60 percent of Canadian families, this figure represents an increase of 13 percent from 1981 and 20 percent from 1971" (p. 339). Hiller and Philliber (1980) hypothesized that the lower the family income, the more likely a woman would be to participate in the workforce (p. 352), their study of over 800 married households supported this (p. 349). In contrast, Herring and Wilson (1993) found that over 46 percent of women reported to be working out of preference, compared to only 19.1 percent due to economic necessity (p. 320). While there is a large difference between the two, one must be aware of the limitations of self-reporting, and that quite simply, not all women have the ability to choose. The other issue at hand is that when women are active in paid labour, they are still faced with gender inequality.

\section{Present Day Employment Limitations - Not a Thing of the Past}

Florence Bird and her colleagues on the RCSW advised the Federal Government to encourage employers to provide more flexibility to women with families: arguing that regular work hours are not conducive to supporting a woman's responsibilities at home (Bird, 1970, p. 117). The report cited employers in the manufacturing industry who had implemented the 
"housewife" or "twilight" shift, allowing a mother to be home with her family for dinner (p. 117). These employees were included in the company's collective agreement and still in receipt of benefits. Bird argued that these flexible shifts not only benefited the employee, but allowed employer's to fill a labour shortage. While feminists today may argue that this is still a far cry from equality, support in this way recognizes that women have other social roles in life. This continues to be an ongoing issue in the paid workforce today as many women are limited to the type of work they can manage alongside that of a household. In conversation with CarrieAnn Galic, a Career Employment Consultant with Alberta Works, she acknowledged this problem in her own area of Spruce Grove, Alberta, particularly with single mothers. CarrieAnn noticed that her income support caseload was saturated with single, employable mothers who were struggling with employment. To counter this, she has spent time in the community fostering relationships with businesses and at this time has secured arrangements with one large retailer that will test out a shift allowing single mothers to be home with their child and not impact child care.

Additionally, while the scope of this paper does not analyze maternity leave benefits in depth, it is an important to acknowledge the role of the program as it relates to women and employment. While the 50 week program is eligible to Canadian women who have the required insurable hours, benefits typically pay only fifty-five percent of a woman's normal salary. It is often not sustainable for families, forcing women back into early employment. (Campbell, 2006, p. 186) Employers are obligated to provide women with the same or equivalent position prior to their leave; however, this is not always the case. As a result, many women may be more likely to experience missed opportunities in regards to employment advancement, and earning potential. While it is seemingly obvious that maternity leave involves an interruption in employment and benefits what may be lesser known are the fears that women have in returning to work. Campbell 
Telford

(2006) found that women were more likely to return to work before their expected date out of concern for their "job responsibilities" and fear of "becoming out of touch with their work" (p. 189).

Women should feel secure in knowing that they have the support of both their employer and multi-levels of government to be absent from work, whether with a new baby or a sick child, without fear of missed opportunity or reprimand. While Canada as a country is lacking a centralized approach to supporting women in employment and child care one province has taken the matter into their own hands.

\section{Quebec - A Leading Province in Child care Reform}

In 1997, the Quebec government implemented a new family policy that put child care at the forefront. The province introduced a $\$ 5$ per day child care rate (later increased to $\$ 7$ in 2004 ) for children in care at least 3 days per week (Albanese \& Rauhala, 2015, p. 256). Premier Lucien Bouchard stated that the policy reflected "the most important values of our society: the meaning of family and love of children" (Cleveland \& Krashinsky, 2001 p. 92). Quebec's child care policy is aimed at "low-income and large families" but all parents, regardless of income or employment status are included (p. 92). It works alongside other policies to combat poverty, and most importantly to ensure equal opportunity and permit parents to work (p. 93). In essence, it is the most inclusive child care policy in Canada. Albanese and Rauhala (2015) found that Quebec women's labour force participation rates, which were below the national average in 1976, had surpassed the average by 2005. Additionally, Ferns and Friendly (2014) found that Quebecois parents were paying the lowest daycare fees in the country (Albanese \& Rauhala, 2015, p. 255). Cleveland and Krashinky (2001) give credit to the Quebec government for assuming full 
Can Canadian Women Have it All?

responsibility of child care and realizing that these services play an instrumental role in “children's development, success in school, and social integration"(p. 93).

\section{Benefits of Early Childhood Care}

In her essay Child Care and Canadian Federalism in the 1990s: Canary in a Coal Mine, Martha Friendly (2000) maintains that while child care is a women's rights issue it could also negatively impact children. Friendly argues that early childhood care benefits the child itself, families, and communities (p. 5). Quebec's child care reform included an education role, which enlisted children at the age of 5 in full-time kindergarten; this is not seen in all provinces across Canada (Cleveland \& Krashinsky, 2001, p. 93). Furthermore, Friendly (2000) believes that this is advantageous for child development and compares children more closely to mainland European nations where "virtually all three to five year olds attend publicly-funded full school-day program" (p. 6). Friendly also attests that while some preschool aged children in Canada attend part-day programs; it is only available to those whose parents can afford the cost (p. 5). In attempt to assist families with the cost of child rearing, whether it be for child care or early childhood education, the government offers a couple of benefits that are the most universal Canada currently has to date.

\section{Federal Government Assistance}

The federal government offers a "universal" family support with child care through two programs, the Live-in Caregiver Program and Universal Child Care Benefit. The Live-in Caregiver program allows an expedited service of foreign workers to enter the country and provide live-in care to a family, with set conditions. The caregiver must provide a minimum of 
Telford

30 hours of care per week, work in a private household, and meet the additional requirements set forth by Employment and Social Development Canada (ESDC) and Citizenship and Immigration Canada (CIC) (ESDC, 2015). While on the surface the intention is to provide support to families while simultaneously supporting foreign workers, this program perpetuates gender, race, and income inequalities (Mckenna, 2015, p. 51). Aside from this, should families use this method of child care, the notion of choice is limited to households whose income can support the cost of paying an employee.

In 2006 the Universal Child Care Benefit (UCCB) was introduced under the Conservative Government to provide support for Canadian residents who are primary caregivers of children under the age of 6, with no income threshold. The program was advertised as additional means to support children and was not appropriated to child care. This replaced the daycare agreements previously held with provincial governments and the young child supplement (Macleans, 2015). In July 2015, the program expanded to include all children under the age of 18; for children aged 5 and under, parents will receive $\$ 160.00$ monthly per child, and those with children between the ages of 6 to 17 will receive a $\$ 60.00$ benefit (CRA, 2015).

The issue that arises with the UCCB is that it simply masks the larger concern of affordable child care; expanding the age group to include families whose children are over six, with no restrictions on funding allocation, gives the illusion that it is advantageous to households. However, the UCCB is a taxable benefit that will in fact do little to support the issue of affordable child care. As Friendly (2000) states "the labour force participation rate of Canadian women with children aged zero to six has been above 65 per cent for some years" (p.6). Albanese and Rauhala (2015) coincide with this idea stating that "as a result [of the UCCB] in most of the country child spaces remain expensive, in short supply, and are perceived, 
both privately and publicly as the individual responsibility of parents" (p. 257). The question that naturally comes to mind is: how are we supporting the large amount of families requiring accessible child care by including school-aged children in the benefit?

\section{What to Expect Going Forward - Liberal Platform}

The results are in: Canadians still want change. A 2006 poll showed that three-quarters of Canadians supported a national child care program (Dallaire \&Anderson, 2009, p. 30). Martha Friendly (2000) believes that the best way to achieve a national child care policy is to have all provinces operating under set principles which would provide consistency across the country (p. 18). The Canadian government has been trying and failing at implementing a national child care strategy for over 45 years, is it possible to untangle set provincial and territorial legislation and create a universal policy?

In October 2015, Justin Trudeau and the liberal government were elected with majority as the new representation for Canada. The Liberal platform states that within the first 100 days of being elected into office the party will work alongside provinces and territories to develop a new "National Early Learning and Child Care" framework. Details of this framework include a Canada Child Benefit (CCB) that is non-taxable and income-tested. This proposal states families whose annual household income is below $\$ 150000$ will receive more than what is currently offered with the UCCB. The party states that "nearly $\$ 20$ billion [dollars] over the next ten years" will be spent on achieving this goal and that there are no plans to "impose pre-determined costs or models" on provincial and territorial jurisdiction (Liberal Platform, 2015). While the idea of more money in the pockets of low-income families' sounds appealing, this platform does not appear to distinguish itself from what history has shown us. Interestingly, the Liberal stance 
Telford

on child care specifically acknowledges that this is needed to provide "economic security for women". Though the seedling of this framework does not stray far from current and past policy, I choose to remain hopeful as Justin Trudeau has openly advocated for women's equality (most notably with his recent response to the Liberal caucus having equal gender representation).

\section{Conclusion}

In the simplest terms, Canadian women and families have the right to a universal child care program. The federal government has a responsibility to provide quality child care support to women and families. Introducing a social-based, centralized policy is multi-beneficial; not only would it further women's equality but also promote good health, encourage positive child development (Friendly, 2000) and assist families in poverty (p. 6). Women have been actively pleading with the government for a quarter of a century to provide this service and today's economic climate shows no sign of addressing the issue on its own.

The other issue at hand is that women should be encouraged and supported in reaching their goals. As noted earlier, not all women work out of economic necessity, many choose to work out of self-fulfillment. A study conducted by Wada et al (2014) coincides with this concept, more women than men in their study reported engaging in paid work as it "stimulated them intellectually and socially" (p. 270.) Accessibility to gender-equal paid employment and child care are not only choices, but human rights.

While I believe the largest effort to change must come from the federal government in supporting all women, it is also important to acknowledge the male role in the household formation. The role a woman plays in society at large as well as the household has changed 


\section{Can Canadian Women Have it All?}

substantially since World War II, however, much like our child care policy, the male household role has been stuck in time.

"I had come to worry about those women who were full-time mothers and homemakers by choice. Did other, more career-minded women have the right to devalue them...? Maybe it was time to slow down and look at the role restrictions imposed not only on women but the men around them, to search for the balance that could promote self-sufficiency..."

- Lin Pardey, Bull Canyon: A Boatbuilder, a Writer, and Other Wildlife 
Telford

\section{References}

Albanese, P., \& Rauhala, A. (2015). A Decade of Disconnection: Child Care Policies in Changing Economic Times in the Canadian Context. International Journal of Child, Youth and Family Studies, 6(2), 252-274-252-274. Retrieved from http:// journals.uvic.ca/index.php/ijcyfs/article/view/13501/4314

Bird, F. et al. Royal Commission on the Status of Women in Canada. Retrieved from http://epe.lac-bac.gc.ca/100/200/301/pco-bcp/commissions-ef/bird1970-eng/bird1970part1-eng.pdf and http://epe.lac-bac.gc.ca/100/200/301/pco-bcp/commissions-ef/ bird1970-eng/bird1970-part2-eng.pdf

Campbell, A. (2006). Proceeding with "Care": Lessons to Be Learned from the Canadian Parental Leave and Québec Daycare Initiatives in Developing a National Child care Policy. Canadian Journal of Family Law, 22(2), 171-222. Retrieved November 18, 2015, from https://library.macewan.ca/library-search/detailed-view/ofs/502628645

Canada Revenue Agency. Enhanced Universal Child Care Benefit. 2015. Retrieved from http://www.cra-arc.gc.ca/gncy/bdgt/2014/qa11-eng.html

Carroll, W. K., \& Shaw, M. (2001). Consolidating a Neoliberal Policy Bloc in Canada, 1976 to 1996. Canadian Public Policy / Analyse De Politiques, 27(2), 195-217. http://doi.org/ $10.2307 / 3552197$

Cleveland, G., \& Colley, S. (2013). Integration of Child Care and Education in Canada: A Comparison with Sweden, New Zealand, England and Wales. International Journal of Early Childhood IJEC, 167-189.

Cleveland, Gordon, and Krashinsky, Michael, eds. Our Children's Future: Child Care Policy in Canada. Toronto, ON, CAN: University of Toronto Press, 2001. ProQuest ebrary. Web. 18 November 2015.

Dobrowolsky, A., \& Jenson, J. (2004). Shifting Representations of Citizenship: Canadian Politics of "Women" and "Children" Social Politics: International Studies in Gender, State \& Society, 154-180.

Employment and Social Development Canada. Families Hiring in-Home Caregivers. Government of Canada. 2015. Retrieved from http://www.cra-arc.gc.ca/gncy/bdgt/2014/ qa11-eng.html

Falkenberg, L., \& Monachello, M. (1990). Dual-Career and Dual-Income Families: Do They Have Different Needs? Journal of Business Ethics, 9(4/5), 339-351. Retrieved from http://www.jstor.org/stable/25072041

Friendly, M., Rothman, L., \& Oloman, M. (1991). Child Care for Canadian Children and Families. Child Welfare League of America/Canada. Retrieved November 19, 2015, from http://www.child carecanada.org/sites/default/files/op1.pdf 
Friendly, M. (2000). Child Care and Canadian Federalism in the 1990s: Canary in a Coal Mine. Child care Resource \& Research Unit Centre for Urban \& Community Studies, 50pp50pp. Retrieved November 18, 2015, from http://childcarecanada.org/sites/default/files/ canaryMFv.pdf

Galic, C.A. Personal Interview. 01 November 2015.

Herring, C., \& Wilson-Sadberry, K.R. (1993). Preference or Necessity? Changing Work Roles of Black and White Women, 1973-1990. Journal of Marriage and Family, 55(2), 314-325. http://doi.org/10.2307/352804

Hiller, D.V., \& Philliber, W.W. (1980). Necessity, Compatibility and Status Attainment as Factors in the Labor-Force Participation of Married Women. Journal of Marriage and Family, 42(2), 347-354. http://doi.org/10.2307/351232

Hutchins, A. \& Robson J. (2015 Jul 18) What You Need To Know About Universal Child Care Benefit. Macleans Magazine. Retrieved from http://www.macleans.ca/economy/ economicanalysis/what-you-need-to-know-about-the-universal-child-care-benefit/

Lipkin, M.R. The Canadian Encyclopedia. (2006). Canadian advisory council on the status of women. Retrieved November 19, 2015 from http://www.thecanadianencyclopedia.ca/en/ article/canadian-advisory-council-on-the-status-of-women/.

Mahon, R. (1997). Child Care in Canada and Sweden: Policy and Politics. Social Politics: International Studies in Gender, State \& Society, 4(4), 382-418. doi:10.1093/sp/4.3.382

Mckenna, E. (2015). "The Freedom to Choose": Neoliberalism, Feminism, and Child care in Canada. Review of Education, Pedagogy, and Cultural Studies, 37(1), 41-52. doi:10.1080/10714413.2015.988529

Morris, C.R. The Canadian Encyclopedia. (2006). Royal commission on the status of women in canada. Retrieved November 19, 2015 from http://www.thecanadianencyclopedia.ca/en/ article/royal-commission-on-the-status-of-women-in-canada/

Pardey, L. (2011). Bull Canyon: A Boatbuilder, a Writer and Other Wildlife. S.1.: Paradise Cay Pubns.

Pasolli, L. (2015). “I ask you, Mr. Mitchell, is the emergency over?” Debating Day Nurseries in the Second World War. Canadian Historical Review, 96(1), 1-31. doi:0.3138

Real Change. Greater Economic Security for Canadians. Liberal Platform. Retrieved from https://www.liberal.ca/files/2015/09/Greater-economic-security-for-Canadianfamilies.pdf

Veterans Affairs Canada. Canada Remember Women on the Homefront. Retrieved from http:// www.veterans.gc.ca/pdf/features/women/whh-fhf.pdf 
Telford

Wada, M., Backman, C., Forwell, S., Roth, W., \& Ponzetti, J. (2014). Balance in Everyday Life: Dual-Income Parents' Collective and Individual Conceptions. Journal of Occupational Science, 21(3), 259-276. doi:10.1080/14427591.2014.913331 